О. Н. Павляк

Калининград

DOI: 10.15393/j9.art.2011.303

\section{ЕВАНГЕЛЬСКИЙ ТЕКСТ В СТРУКТУРЕ СТИХОТВОРЕНИЯ М. М. ХЕРАСКОВА «ИИСУС ДРУГ ГРЕШНИКОВ»}

У читывая, что текст стихотворения М. М. Хераскова
в советское время не печатался, считаем возможным привести его полностью.

\section{Сей грешники приемлет.}

Ев. Луки, гл. 15, cm. 1-7

Спаситель грешного приемлет!

Та истина гремит вовек.

Что слух в законе Ветхом внемлет,

Что Бог в его уставах рек,

Адаму было что внушенно,

Мойсеом что изображенно,

Что глас Пророческий вещал,

Апостол ${ }^{1}$ перстом указал,

Все учит нас и вразумляет,

Спаситель грешных принимает.

Уста сыновния вещали;

Словам его внимал Отец,

И праведны глаголы стали!

Дух Божий живо наконец

В Апостольских посланьях дышет,

Рукой Петра и Павла пишет,

Приемлет грешных и прощает,

Сомненья кающимся нет;

То небо день и нощь вещает

И Господу хвалы поет.

Лишь только грешник умилится,

Небесна твердь возвеселится.

В той истине и тартар сам,

Затрепетав, не спорит нам;

И тамо Ангел падший внемлет:

Спаситель грешников приемлет!

Сие вещают звездны круги,

Моря и горы вопиют,

Господние враги и други

Единогласно признают.

Но кто ж сей истине не верит?

Который с Богом лицемерит,

\footnotetext{
(C) Павляк О. Н., 2011

${ }_{1}^{1}$ Апостол, как указывает в примечании автор, - Иоанн Ев<анге-
} лист $>$.
Во Иоанне Он речет,

Не может ближнего терпеть

И весь благочестивый свет

В грехе намерен умереть.

Священные глаголы внемлет:

Но пусть он в смертной сени дремлет,

Спаситель грешников приемлет!

Спаситель грешников приемлет!

Сей глас из века в век твердился, Внушенный в древности Творцом

Лишь только первый появился

Несчастный грешник в мире сем.

Хоть мир бы целый усомнился И правды сей не признавал,

Спаситель бы не пременился,

К Себе б как пастырь грешных

Спроси, спроси о нем Адама,

У Ноя, иль у Авраама,

Спроси у наших праотцов,

Спроси у истинных сынов;

Повсюду слух преданье внемлет:

Спаситель грешников приемлет!

То слово веки утвержденно,

К кресту Господню пригвожденно;

Печатью вечной нам дано

И кровью писано оно.

Из уст Мессии каждый внемлет:

Спаситель грешников приемлет! ${ }^{2}$

Мысль об особой роли Библии в литературе, начиная от самых истоков ее зарождения и до наших дней, не нуждается в доказательствах. Библейские темы, сюжеты, мотивы, ситуации, пронизанные неисчерпаемой метафорической глубиной, на протяжении многих веков становились не только вдохновляющим животворящим источником для художника, но и входили в структуру литературного текста как важнейшая семантическая составляющая, формирующая его нравственно-психологический, историко-философрский и художественный потенциал.

Для литературы XVIII века обращение к библейскому тексту, к идеям, сокрытым в нем, выполняло своего рода «охранительную» задачу. Библейский текст нужен был не только для того, чтобы выйти на сущностные для человека проблемы бытия, но и для того, чтобы утвердить и защитить христианскую веру как таковую, на художественном уровне утвердить ее важнейшие нравственно-религиозные постулаты. К числу таких произведений относится стихотворение М. М. Хераскова «Иисус друг грешников».

${ }^{2}$ Херасков М. М. Иисус друг грешников // Христос в русской поэзии XVII-XX вв. M., 2001. С. 79-82. Далее цитаты приводятся по этому изданию с указанием страницы в тексте статьи. Курсив в цитатах наш. 
Поэтический текст предваряется эпиграфом из Евангелия от Луки: «Сей грешники приемлет» (Лк. 2:79). Приводя эту строчку, Херасков дает следующую отсылку: «Ев. Луки, гл. 15, ст. $1-7 »$ и тем самым вовлекает в художественное пространство всю притчу о кающемся грешнике. Речь в ней идет о милосердии, проявленном Иисусом, о спасении людей, отставших от Бога:

...порадуйтесь со мною: я нашел свою пропавшую овцу. Сказываю вам, что так на небесах более радости будет об одном грешнике кающемся, нежели о девяносто девяти праведниках, не имеющих нужды в покаянии (Лк. 15:6-7).

Таким образом, благодаря эпиграфру актуализируется целый комплекс важнейших христианских идей: идея милости Божьей, спасения, покаяния и, конечно, идея торжества благодати над законом. «Грех не должен над вами гос-подствовать, ибо вы не под законом, но под благодатью», - сказано апостолом Павлом в послании к Римлянам (Рим. 6:14). В христианском понимании всякий человек «имеет природу испорченную и подверженную греху»³. «Писание показало, что всякий человек есть грешник» ${ }^{4}$. Говоря о драме грехопадения, митрополит Кирилл обозначает ключевую мысль:

Драма грехопадения, имевшая столь опасные для людей последствия, включает в себя также и обетование о пришествии Спасителя мира и о грядущем искуплении ${ }^{5}$.

В этом заключается великая надежда на спасение. Эпиграфр «Сей грешники приемлет» представляет универсальную по своему звучанию поэтическую формулу, предваряющую лирический сюжет. Адресат, к которому она обращена, это «все» и «каждый».

Заглавие продолжает удерживать намеченный масштаб адресации, но при этом ориентирует на некий смысловой и эмоциональный сдвиг от «всех» к «каждому». «Иисус друг грешников» - слово «друг» фриксирует совершенно особый

${ }^{3}$ Митрополит Слоленский и Калининградский Кирилл. Слово пастыря. М., 2004. С. 46.

4 Библейский богословский словарь. М., 1995. С. 86.

5 Митрополит Слоленский и Калининградский Кирилл. Указ. соч. C. 49 . тип отношений между Иисусом и грешником, его первоначальное значение: «спутник, товарищ на войне» ${ }^{6}$. Слово спутник, производное от слова «сопутье», - «общий с кем путь, попутье, одна дорога» ${ }^{7}$. Итак, друг - это, прежде всего, человек, идущий с кем-либо одним путем. Кроме того, слово «друг» обозначает «равный, ближний» ${ }^{8}$, то есть в этой коннотации проявляется очень высокая степень близости. Друг - это не просто попутчик, но человек близкий, человек, которому доверяешь. Однако у слова «друг» есть и другое значение: "всякий человек другому». Еще один важный смысловой оттенок заключается в том, что «друг»это «равный и близкий», но «другой», то есть слово фокусирует значение близости и одновременно границы. В христианском религиозном пространстве слово «друг» имеет особое значение. Обращаясь к апостолам на Тайной вечере, Иисус говорит:

Я уже не называю вас рабами: ибо раб не знает, что делает господин его; но Я назвал вас друзьями, потому что сказал вам все, что слышал от Отца Моего (Ин. 15:15).

Е. Н. Трубецкой, размышляя над этими словами из Евангелия, пишет:

Божественная любовь хочет иметь в человеке не автомата, а друга. В этом и есть оправдание свободы: без свободы нет дружества, а без дружества нет любви. Любовь есть по самому существу своему жизненное отношение $\kappa$ другому ${ }^{9}$.

Bce призваны быть друзьями, членами тела Христова ${ }^{10}$.

Таким образом, в названии ассоциативно формируется целая система отношений между Творцом и человеком. Если же все эти оттенки смыслов использовать для интерпретации заглавия, то получается следующая картина: «Иисус друг грешников», где Иисус - цель и путь, ведущий грешника ко спасению, это путь любви, веры и доверия,

${ }^{6}$ Шанский Н. М., Иванов В. В., Шанская Т. В. Краткий этимологический словарь русского языка. М., 1971. С. 133.

7 Даль В. И. Толковый словарь живого великорусского языка: В 4 т. M., 2001. T. 4. C. 130 .

${ }^{8}$ Там же. Т. 1. С. 452

${ }^{9}$ Трубецкой Е. Н. Смысл жизни. М., 2000. С. 125.

10 Там же. С. 162. 
«друг» - это все «грешные» люди и каждый «грешник» в отдельности, обладающий дарованной Творцом свободой.

Таким образом, эпиграф из Евангелия и название стихотворения задают вектор движения лирического сюжета, конечная точка которого уже обозначена. Собственно говоря, внутрисюжетное движение определяется не поиском ответа на тревожащий автора вопрос, а утверждением непреложной истины. Выражена она поэтической формулой «Спаситель грешного приемлет!», и, по существу, это авторское изложение евангельской мысли, заключенной в эпиграфре. Создается своего рода трехступенчатая система вхождения в лирическую ситуацию: эпиграфр, где звучит слово Божье, затем название и первый стих, представляющие собой авторское слово, оно позволяет привнести свой духовный опыт, и таким образом приблизить и укрепить выраженную в Евангелии ценность в ее, так сказать, личностном восприятии. Эта смысловая парадигма включает в себя огромный пласт евангельского знания, ассоциативно стоящего за текстом, о чем уже говорилось выше, и формирует тезу, которую предстоит провести через серию испытаний, чтобы утвердить в финале ее незыблемость. Первый стих - «Спаситель грешного приемлет!», являясь частью трехступенчатой системы, становится ее знаком, делегирующим всю смысловую целостность. Эти слова не только открывают лирический сюжет, но и завершают каждую строфру, всякий раз включая всю ассоциативную цепь.

Стихотворение делится на шесть строф, центральная мысль выражена в фоинальных стихах: «Спаситель грешного приемлет». В первой строфе она высказана дважды в начале и конце.

Спаситель грешного приемлет!

Та истина гремит вовек.

Что слух в законе Ветхом внемлет,

Что Бог в его уставах рек,

Адаму было что внушенно,

Мойсеом что изображенно,

Что глас Пророческий вещал,

Апостол перстом указал,

Все учит нас и вразумляет,

Спаситель грешных принимает.

$(79-80)$
Архитектоника стихотворения представляет собой цикличное образование, в котором каждая строфра призвана на новом витке развития лирического сюжета утвердить заявленную трехступенчатым началом тезу.

В первой строфре авторскому высказыванию «Спаситель грешников приемлет!» придается характер вневременного умозаключения: «Та истина гремит вовек». Далее создается абсолютно рациональная структура доказательств, где каждая последующая строчка, а затем и строфра соединены с предыдущей четкой логической связью. И если первый стих обнаруживает тезу, то следующий придает ей вневременной масштаб («вовек»), который, в свою очередь, нуждается в последующих доказательствах. Слово «вовек» обнаруживает движение времени от прошлого к настоящему и будущему, укрепляя статус постоянства утверждаемой истины («Сей глас из века в век твердился / Внушенный в древности Творцом»- «И весь благочестивый свет / Священные глаголы внемлет»). Она была провозглашена в Ветхом завете («Что слух в законе Ветхом внемлет / Что Бог в его уставах рек») и закреплена в Евангелии («Что глас пророческий вещал, / Апостол перстом указал») и будет существовать всегда.

Лирическое событие представляет все пространство Бога, включающее в себя: небо («небесная твердь»- Горний мир); землю («мир» людей); подземелье (преисподнюю «тартар» - пристанище дьявола). Таким образом, истина, провозглашенная в Евангелии («Сей грешники приемлет»), показана звучащей не только всегда («вовек»), но и везде (на небесах, на земле, под землей).

Бог в стихотворении выступает в трех ипостасях: Отец («Творец», «Отец») - Сын («Иисус», «Спаситель») - Святой Дух («Дух Божий»), что в полной мере отражает учение о троичном Боге, данное «с полной определенностью в Новом Завете» ${ }^{11}$. Представление Бога в трех лицах ассоциативно привносит в текст важнейшую христианскую идею любви.

${ }^{11}$ Христианство: Энциклопедический словарь: В 3 т. М., 1995. Т. 3. ${ }^{11} \mathrm{Xp}$
C. 389 . 
Человек в сюжете стихотворения обозначен несколькими смысловыми парадигмами, с соблюдением историко-религиозной иерархии.

Сей глас из века в век твердился,

Внушенный в древности Творцом,

Лишь только первый появился

Несчастный грешник в мире сем.

Спроси, спроси о нем Адама,

У Ноя, иль у Авраама,

спроси у наших праотцов

«Ветхозаветная» парадигма («праотцов»): первый человек и отец рода человеческого - Aдал; праведник, родоначальник послепотопного человечества - Ной; родоначальник еврейского народа, постигший существование единого Бога - Авраал; вождь израильского народа, автор пяти книг Ветхого завета, пророк, «которого Господь знал лицом к лицу» (Втор. 34:10), - Моисей. Автор прибегает к именам людей, чье значение в истории человечества едва ли можно переоценить, чтобы провозглашенная тезой истина («Спаситель грешников приемлет») приобрела еще большую убедительность. Ведь именно они должны подтвердить ее силу сомневающемуся грешнику.

«Новозаветная» парадигма («сынов»): Петр - ученик Христа, первый провозгласивший Его «Христом, Сыном Бога живого», удостоенный названия «камня», на котором основана Церковь (Мфp. 16:17-19); Павел - названный «апостолом язычников», совершивший путь от гонителя в великого проповедника христианства; Иоанн - евангелист, ученик, «которого любил Иисус» (Ин. 19:26). Все они являются авторами апостольских посланий, то есть людьми, «получившими от Бога повеление для сообщения людям ${ }^{12}$. И в тексте их фрункция вполне соответствует этому великому предназначению, именно они, Петр, Павел и Иоанн, несут в мир слово Божье:

$$
\begin{aligned}
& \text { Уста сыновния вещали; } \\
& \text { Словам его внимал Отец, } \\
& \text { И праведны глаголы стали! } \\
& \text { Дух Божий живо наконец }
\end{aligned}
$$

12 Там же. Т. 1. С. 109. В Апостольских посланьях дышет,
Рукой Петра и Павла пишет,

Во Иоанне Он речет

Третью парадигму как раз и составляют люди, до которых доносится слово Божье: «весь благочестивый свет»«кающийся грешник» - и тот, к кому не пришло раскаяние («который с Богом лицемерит... в грехе намерен умереть»).

В едином божественном пространстве земной «кающийся грешник» получает небесную весть о прощении («То небо день и ночь вещает») и приходит в умиление («Лишь только грешник умилится»). Слово «умиление» содержит в себе целый комплекс чувств, свидетельствующих о глубоких нравственных изменениях. Умилять — «возбуждать нравственные чувства, любовь, жалость», умиление пробуждает «чувство покойной, сладостной жалости, смирения, сокрушения, душевного радушного участия, доброжелательства» ${ }^{13}$. Уместно заметить, что слово "умиление» этимологически восходит к слову молиться (лилити ${ }^{14}$ ) и, значит, на этимологическом уровне содержит коннотацию обращения к Богу. Все это вместе: и нравственная перемена, и сокрытая в этимологических корнях мысль о молитве подготавливают ответ «умиленному» грешнику:

$$
\text { Лишь только грешник умилится }
$$$$
\text { Небесна твердь возвеселится. }
$$

Создается логическая цепочка, фиксирующая движение неба к человеку и человека к небу. При этом движение человека к небу выявляет важное условие - нравственное преобразование грешника, и обнаруживает путь к этому раскаяние и молитву.

Пространство, в котором пребывает дьявол, представлено локусом «тартар» ${ }^{15}$ (ад, преисподняя) и фригурой падшего Ангела.

В той истине и тартар сам, Затрепетав, не спорит нам;

${ }^{13}$ Даль В. И. Указ. соч. Т. 4. С. 306.

${ }^{14}$ Шанский Н. М., Иванов В. В., Шанская Т. В. Указ. соч. С. 465.

${ }^{15}$ Следует заметить, что античное название «тартар» скорее дань европейской традиции, нежели культурно-религиозная маркировка, принадлежащая соответствующей эпохе. 
И тамо Ангел падший внемлет:

Спаситель грешников приемлет.

Структурный принцип укрепления провозглашенной истины («Спаситель грешников приемлет!») в пространстве преисподней тот же, что и в пространстве земли, где «все» - это «Весь благочестивый свет», а «каждый» - любой «грешник». В данном случае «все» - это весь мир преисподней — «тартар», а «каждый» — это конкретное существо этого мира - «Ангел падший». Таким образом, и в пространстве земли, и в пространстве подземелья (преисподней), и в мире фризическом, и в мире метафизическом «все» и «каждый» «внемлют» истине:

Спаситель грешников приемлет!

Структурное сходство в построении доказательств еще один способ, но уже на уровне организации текста, позволяющий утвердить мысль о том, что для этой истины границ между пространствами не существует. В сюжете стихотворения запечатлен момент победы христианской истины над миром «тартара» («Затрепетав, не спорит нам»), и, следовательно, отстаиваемая истина («Спаситель грешников приемлет!») оказывается над вековечной ситуацией, тем самым автор определяет ее приоритетное место в системе христианских ценностей.

Лейтмотивом стихотворения является мотив живого слова. Он воплощается в двух качествах - слово производимое (звучащее или написанное) и слово воспринилаелое.

\section{Слово производимое}

«истина гремит», «Бог рек»,

«Адаму внушено», «Глас

вещал», «уста вещали»,

«глас твердился»,

«день и ночь вещает»,

«хвалу поет», «моря и горь

вопиют», «пастырь звал»,

«праведны глаголь»», «Он речет».

Следует заметить, что слово производимое выражено разными глаголами, а слово воспринилаелое - во всех случаях, кроме одного, только одним: «внимать», то есть «слушать». Этимологические корни слова «внимать» обнаруживают важный смысловой нюанс: оно образовано при помощи приставки «в» от илиати - «брать» ${ }^{16}$. Привычное двухфазовое движение, определяющее процесс общения: говорить - слушать, писать - читать, во второй фразе подменяется одним глаголом: внилать, то есть слушать и брать одновременно. Таким образом, фриксируется сам момент принятия истины. Иначе говоря, глагол внилать обозначает не только процесс - «слушать», но и его конечный результат — «брать». Если «Дух Божий... речет», то «благочестивый свет... внимает», то есть истина не просто услышана, но воспринята «светом», и это начинает определять качество "света» - «благочестивый», то есть «по истине почитающий Бога» ${ }^{17}$. Слово как сущностный фрактор играет преобразующую роль и становится важнейшей структурной единицей лирического сюжета. В конце стихотворения слово, употребленное в евангельском смысле (о чем более подробно будет сказано несколько позже), ретроспективно накладывает отпечаток на образ "всего света", придавая ему статус внимающего - вне времени и пространства. Структурно-этимологический анализ слова «благочестивый» позволяет выявить его дополнительные смысловые оттенки: «благо» - заимств. из ст.-сл. «добро, счастье» ${ }^{18}$, «честь» - общеслав. образовано с помощью суфр. - $m b$ от чьсти, чьmу - «почитать, читать» ${ }^{19}$. Если реконструировать первоначальный прямой смысл двух основ слова «благочестие», то оно может быть прочитано как «читающий добро». Очевидно, что в такой конструкции недостает важного звена, которое легко восстанавливается: «читающий [слово] добра». Таким образом, в самой конструкции двусоставного слова «благочестие» сокрыто слово как таковое.

Дальнейший анализ подтверждает возможность такого прочтения, поскольку выявляет ключевую позицию слова в структуре текста. Уже говорилось о том, что мотив живого слова формирует сюжет. Последняя строфа целиком

${ }^{16}$ Шанский Н. М., Иванов В. В., Шанская Т. В. Указ. соч. С. 86.

${ }_{17}$ Даль В. И. Указ. соч. Т. 1. С. 132.

${ }_{18}$ Шанский Н. М., Иванов В. В., Шанская Т. В. Указ. соч. С. 47.

19 Там же. С. 493. 
посвящена слову как основополагающему христианскому понятию.

Хоть мир бы целый усомнился

И правды сей не признавал,

Спаситель бы не пременился,

К Себе б как пастырь грешных звал.

То слово ввеки утверждено,

К кресту Господню пригвожденно;

Печатью вечной нам дано;

И кровью писано оно.

Из уст Мессии каждый внемлет:

Спаситель грешников приемлет!

$$
(81-82)
$$

В фринальной позиции истина «Спаситель грешников приемлет!», редреном проходящая через все лирическое высказывание, получает маркировку - (то) «слово». Размещена она ровно в середине строды, обретая тем самым и на формальном уровне центральную позицию, своего рода ключ ко всему размышлению. Слово в тексте имеет евангельский ассоциативный ореол, оживляющий в сознании читателя первые строчки Евангелия от Иоанна:

В начале было Слово, и Слово было у Бога, и Слово было Бог (Ин. 1:1).

Возникает такая ассоциативная связь, во-первых, потому что весь ход развития лирического сюжета, начиная с эпиграфра, происходит в евангельском духовном пространстве; во-вторых, именно слову доверена функция аккумулирования самой сути важнейшей христианской идеи искупительной смерти Иисуса Христа («Печатью вечной нам дано»). «Слово», несмотря на безусловную метафоричность, представлено с большой долей эмпирической определенности: оно «утверждено», «пригвождено», дано «печатью», писано «кровью». Говоря иначе, слово становится предметно-осязаемой сущностью, в самой себе заключающей сокровенный смысл главной идеи христианства. Ключевая позиция слова имеет и глубокую фрилософрскую подоплеку. Движение к конечной цели христианина - ко спасению показано M. М. Херасковым в контексте Божественного замысла: «...мир бы усомнился» - «Спаситель бы не пременился». В этом утверждении автор в художественной форме выразил глубоко фрилософрскую мысль о том, что для человека цель и путь к победе - ко спасению - в сотворенном мире проходят во времени.

В Боге же эта победа от века достигнута ${ }^{20}$.

Евгений Трубецкой, размышляя о мировой эволюции, говорит о том, что если для человеческого сознания есть «психологическая граница», в силу которой явление Христа представляется историческим моментом, то «для всеединого сознания Боговоплощение есть альфа и омега истории, ее начало и конец, который везде присутствует, к которому все стремится и о котором все свидетельствует. Всеединое сознание, для которого все открыто, видит Христа везде - в горении светил, и в сонном прозябании растений, и в томлении мира животного, в его подъеме к человеку и, наконец, в заключительном явлении вечного Слова в центре человеческой истории» ${ }^{21}$. Именно в значении «вечного Слова» прозвучала в стихотворении М. М. Хераскова мысль о спасении грешников, придавая всему высказыванию не только этическую и историческую глубину, что отвечало требованиям века Просвещения, но и глубину религиозно-фрилософркую.

Обращение к сущностным, вневременным основам бытия сообщает этому тексту особый статус. Оставаясь, безусловно, рационалистическим по форме и выполняя просветительскую и морализаторскую задачу, стихотворение М. М. Хераскова, благодаря полноте художественного воплощения мотива звучащего слова, обретает собственно лирическое содержание. Пафрос отстаивания ценностей христианской картины мира выводит это поэтическое высказывание за рамки исключительно умозрительного заключения, сообщая характер личностного переживания.

\footnotetext{
${ }^{20}$ Трубецкой E. Н. Указ. соч. С. 121

${ }^{21}$ Там же. C. 120.
} 